\title{
Analisis Strategi Peningkatan Daya Saing Sayuran Organik
}

\author{
Dila Priastuti \\ Departemen Manajemen, Fakultas Ekonomi dan Manajemen \\ Institut Pertanian Bogor \\ Kampus Darmaga Bogor 16680 \\ Arif Imam Suroso \\ Departemen Manajemen, Fakultas Ekonomi dan Manajemen \\ Institut Pertanian Bogor \\ Kampus Darmaga Bogor 16680 \\ Mukhamad Najib \\ Departemen Manajemen, Fakultas Ekonomi dan Manajemen \\ Institut Pertanian Bogor \\ Kampus Darmaga Bogor 16680 \\ e-mail: mnajib23@yahoo.com
}

\begin{abstract}
The increasing of public awareness on healthy lifestyles currently influence Indonesian consumer's trend to consume healthy food such as organic food. Public awareness about health will increase the demand for organic vegetables. This phenomenon push higher competition among producers of organic vegetables. The purposes of this research are : 1) analyze factors of condition affecting competitiveness of organic vegetable; 2) analyze strategy for enhancing competitiveness of organic vegetable; 3) analyze strategic priority to enhance competitiveness of organic vegetable. Primary data was collected by indept interview with respondents chosen by convineance sampling methods. Porter diamond and five forces models has been used to analyze external factors and factors of competitiveness of organic vegetables. Analytical Hierarchy Process (AHP) has been used to determine the best strategy. The highest of factor analysis are capital, natural and environmental resources, infrastructure and power supplier while the lowest value is the influence of a replacement product. Highest priority that can be chosen as an alternative strategy is building a positive image in the industry.

Keywords: strategy analysis, competitivenes, organic vegetables.
\end{abstract}

\begin{abstract}
ABSTRAK
Meningkatnya kesadaran masyarakat terhadap gaya hidup sehat akhir-akhir ini, mempengaruhi kecenderungan konsumen Indonesia untuk mengkonsumsi makanan sehat seperti makanan organik. Kesadaran masyarakat tentang kesehatan akan meningkatkan permintaan untuk sayuran organik. Fenomena ini mendorong persaingan antara produsen sayuran organik yang semakin tinggi. Penelitian ini bertujuan: 1) Menganalisis faktor kondisi yang mempengaruhi daya saing sayuran organik; 2) Menganalisis strategi peningkatan daya saing sayuran organik; 3) Menganalisis prioritas strategi peningkatan daya saing sayuran organik. Data primer diperoleh wawancara dengan responden yang dipilih dengan menggunakan conveniance sampling. Model berlian Porter dan model lima kekuatan Porter digunakan untuk melihat faktor-faktor eksternal dan faktor kondisi daya saing dari sayuran organik. Analytical Hierarchy Process (AHP) digunakan untuk menentukan strategi terbaik. Faktor tertinggi dari hasil analisa adalah sumberdaya modal, sumber daya alam dan lingkungan, infrastruktur
\end{abstract}


dan kekuatan pemasok, sedangkan nilai terendah adalah pengaruh produk pengganti. Prioritas tertinggi yang dapat dipilih sebagai strategi alternatif adalah membangun citra positif dalam industri.

Kata kunci: analisis strategi, daya saing, sayuran organik.

\section{Pendahuluan}

Sektor pertanian adalah sektor dengan kekuatan yang besar di Indonesia. Indonesia sebagai negara agraris memiliki kondisi alam yang baik sehingga dapat menghasilkan produk-produk pertanian. Hal ini ditunjang pula dengan mata pencaharian penduduk yang sebagian besar adalah petani. Salah satu hasil pertanian yang potensial adalah sayuran. Jumlah sayuran yang dihasilkan cenderung meningkat tiap tahunnya (Gambar 1)

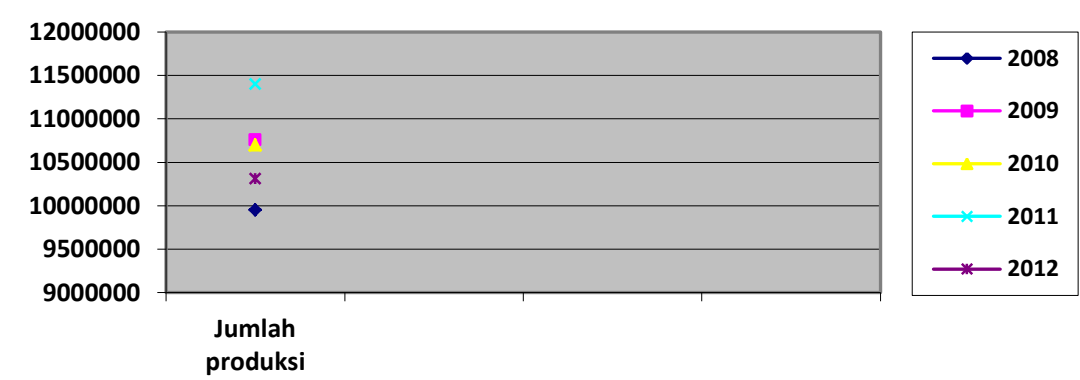

\begin{tabular}{|c|c|c|c|c|c|}
\hline $\begin{array}{c}\text { Jumlah } \\
\text { produksi } \\
\text { (Ton) }\end{array}$ & 2008 & 2009 & 2010 & 2011 & $\begin{array}{c}2012 \\
\text { (sementara) }\end{array}$ \\
\cline { 2 - 6 } & 9.950 .107 & 10.753 .419 & 10.699 .420 & 11.394 .891 & 10.307 .123 \\
\hline
\end{tabular}

Gambar 1. Jumlah produksi sayuran di Indonesia (BPS 2013)

Pada era globalisasi ini, masyarakat mulai menyadari pentingnya kesehatan melalui pengkonsumsian makanan-makanan sehat yang diharapkan akan memberikan efek lebih baik untuk tubuhnya. Masyarakat mulai beralih mengkonsumsi bahan makanan sehat seperti lebih banyak mengkonsumsi buah dan sayuran. Setiap tahunnya, sayuran yang dikonsumsi semakin meningkat jumlahnya. Hal ini dapat dilihat dari rataan konsumsi sayuran oleh penduduk Indonesia yang tiap tahun semakin bertambah, seperti di muat pada Tabel 1.

Tabel 1. Rataan konsumsi sayuran penduduk Indonesia

\begin{tabular}{ccc}
\hline Tahun & $\begin{array}{c}\text { Jumlah Rataan Konsumsi } \\
(\text { Kg/Kapita/Tahun) }\end{array}$ & Kenaikan (Kg) \\
\hline 2007 & 40.90 & - \\
2008 & 41.32 & 0.42 \\
2009 & 43.5 & 2.18
\end{tabular}

Sumber: Direktur Jenderal Holtikultura (2010)

Saat ini sayuran telah dibudidayakan dalam bentuk sayuran organik. Peningkatan jumlah produksi sayuran organik di Indonesia sendiri terjadi akibat dari adanya peningkatan luas lahan sayuan organik. Pada Gambar 2 disajikan pertumbuhan luas lahan sayuran organik di Indonesia. 


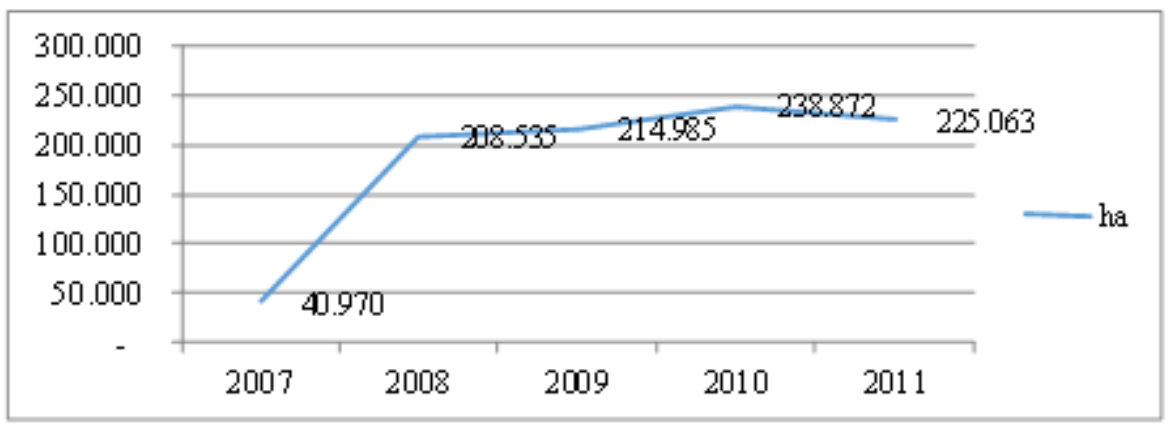

Gambar 2. Perkembangan luas area pertanian organik Indonesia 2007-2011 (AOI 2011)

Semakin luasnya lahan sayuran organik di Indonesia dari tahun 2007 sampai 2011 yang mengalami peningkatan luas lebih dari 180000 ha, mengidentifikasikan semakin banyaknya permintaan konsumen akan sayuran organik. Manfaat yang diberikan untuk tubuh akan lebih baik bila dibandingan sayuran yang di tanam dengan menggunakan pestisida, maka dari itu, ditunjang dengan semakin tingginya kesadaran masyarakat dalam mengkonsumsi sayuran sehat serta kemudahan dan kegemaran masyarakat dalam mengkonsumsi sayuran organik ini, maka potensi yang dimiliki oleh Indonesia dalam memproduksi sayuran sayuran organik dan selalu meningkatnya permintaan pasar akan sayuran tersebut dapat dimanfaatkan oleh pelaku usaha yang bergerak di bidang agribisnis sayuran organik untuk memenuhi permintaan pasar serta mengembangkan usahanya. Meningkatnya pelaku usaha sayuran organik berarti meningkat pula persaingan dalam memenangkan pasar. Oleh karena itu diperlukan analisis untuk merumuskan strategi terbaik dan tepat untuk dapat meningkatkan keunggulan kompetitif tersebut.

Tujuan yang ingin dicapai dari penelitian ini adalah 1) Menganalisis faktor-faktor kondisi yang mempengaruhi daya saing sayuran organik; 2) Menganalisis strategi dalam meningkatkan daya saing sayuran organik; 3) Menganalisis prioritas strategi yang telah disusun untuk meningkatkan daya saing sayuran organik.

\section{Metode Penelitian}

Penelitian ini dilakukan di Bogor, Jawa Barat. Pemilihan lokasi dilakukan secara sengaja dengan pertimbangan bahwa Bogor merupakan salah satu daerah penghasil sayuran organik. Waktu penelitian dilaksanakan pada bulan Mei hingga Juli 2013. Data yang digunakan adalah data primer yang diperoleh melalui kuesioner dengan metode survei dan data sekunder yang diperoleh dari studi kepustakaan dengan mempelajari dan menelaah berbagai literatur yang berhubungan dengan penelitian.

Metode pengambilan contoh yang digunakan adalah wawancara khusus (Elite Interviewing). Sejumlah 5 responden digunakan dalam penelitian ini. Pemilihan responden difokuskan pada pakar atau ahli yang mengetahui tentang daya saing sayuran organik. Responden yang dipilih meliputi akademisi, produsen sayur organik, Pemerintah Daerah Bogor, Dinas Pertanian Bogor dan Kementerian Pertanian. Alur kerangka pemikiran dalam penelitian ini dapat dilihat pada Gambar 3. 


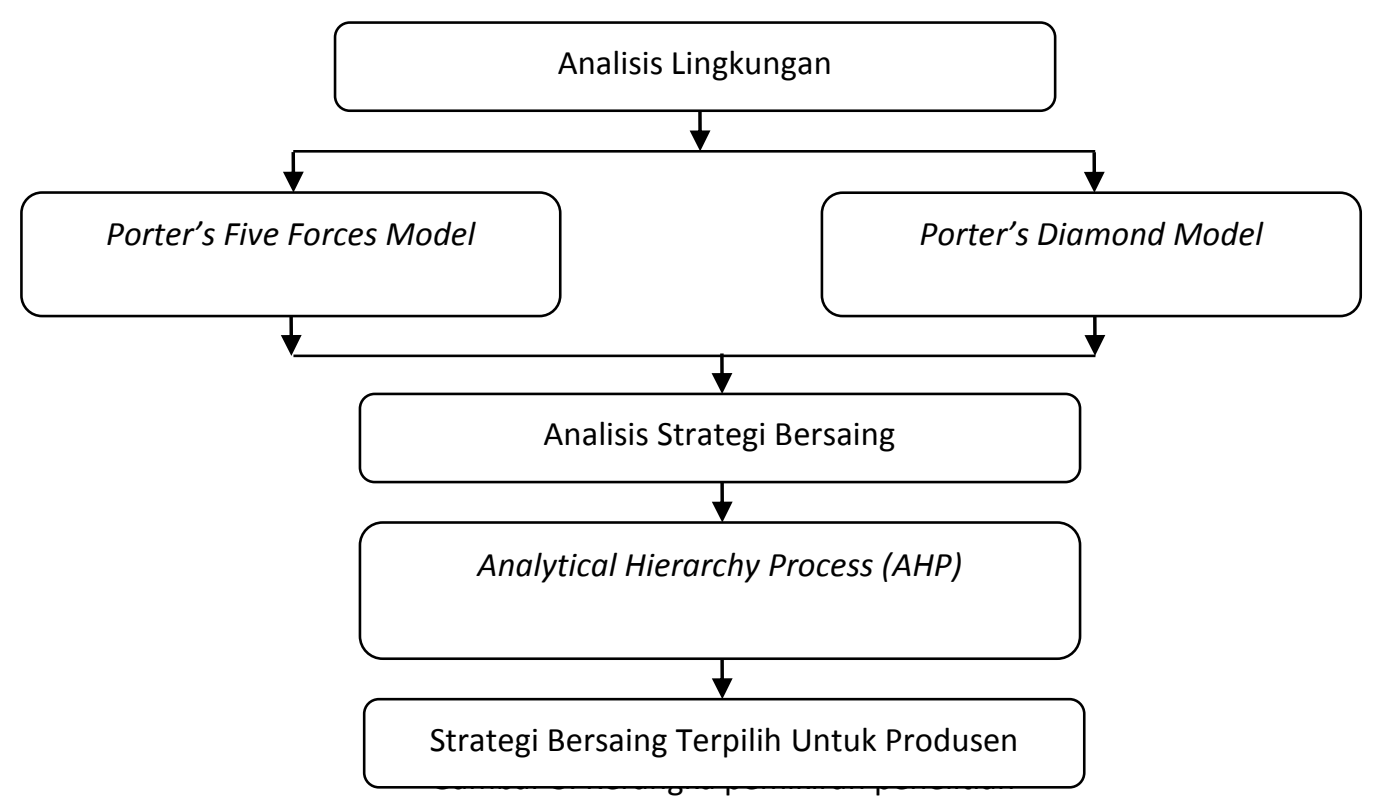

Gambar 3. Kerangka pemikiran penelitian

Data diperoleh melalui kuesioner dan wawancara, setelah itu dilakukan analisis menggunakan Porter's diamond model dan Porter's five forces model untuk mengetahui faktor-faktor kondisi yang memengaruhi peningkatan daya saing sayuran organik. Tambunan (2013) mendefiniskan bahwa daya saing adalah kemampuan suatu komoditi untuk masuk ke dalam pasar dan kemampuan untuk bertahan dalam pasar tersebut. Secara konsep daya saing dibagi menjadi dua, yaitu keunggulan kompetitif (competitive advantage) dan keunggulan komparatif (comparative advantage) (Munandar 2011). Dalam Porter's Diamond Model, diidentifikasi empat faktor yang menentukan daya saing. Keempat faktor tersebut adalah faktor kondisi, kondisi permintaan, industri terkait dan industri pendukung, serta ketatnya persaingan. Peranan pemerintah dan peluang memiliki peranan yang penting dalam menentukan daya saing. Porter's Five forces Model, menurut identifikasi yang dilakukan oleh Poter (2007), sebuah perusahan bergantung kepada lima kekuatan yang akan menentukan keberlangsungan hidup.

Selanjutnya digunakan Porter's Generic Strategic untuk menentukan strategi daya saing. Porter (2007) menjelaskan terdapat tiga pendekatan strategi generik yang secara potensial akan berhasil menggungguli perusahaan lama suatu industri, yaitu keunggulan dalam biaya menyeluruh, diferensiasi dan fokus. Tahap terakhir digunakan Analytical Hierarchy Process (AHP) untuk menentukan alternatif strategi yang akan dijalankan. Pemilihan atau penyusunan prioritas dilakukan dengan suatu prosedur logis. Kuesioner yang digunakan dalam penelitian ini berdasarkan pada konsep Porter's dan terstruktur. Menurut Saaty (1991), beberapa prinsip dalam menyelesaikan AHP diantaranya identifikasi sistem, penyusunan struktur, membuat matriks perbandingan komparasi berpasangan, melakukan tahap perbandingan dan penilaian, semua data banding berpasang itu dan memasukkan nilai-nilai kebalikannya beserta bilangan 1 sepanjang diagonal utama, prioritas dicari dan konsistensi diuji, menggunakan komposisi secara hirarki (sintesis) untuk membobotkan vektor-vektor prioritas itu 
dengan bobot kriteria-kriteria dan menjumlahkan semua nilai prioritas terbobot yang bersangkutan dengan nilai prioritas dari tingkat bawah berikutnya dan seterusnya. Hasilnya adalah vektor prioritas menyeluruh untuk tingkat hierarki paling bawah.Jika hasilnya ada beberapa, maka diperbolehkan diambil nilai rataan aritmetiknya. Kerangka AHP dalam penelitian ini dapat dilihat pada Gambar 4.

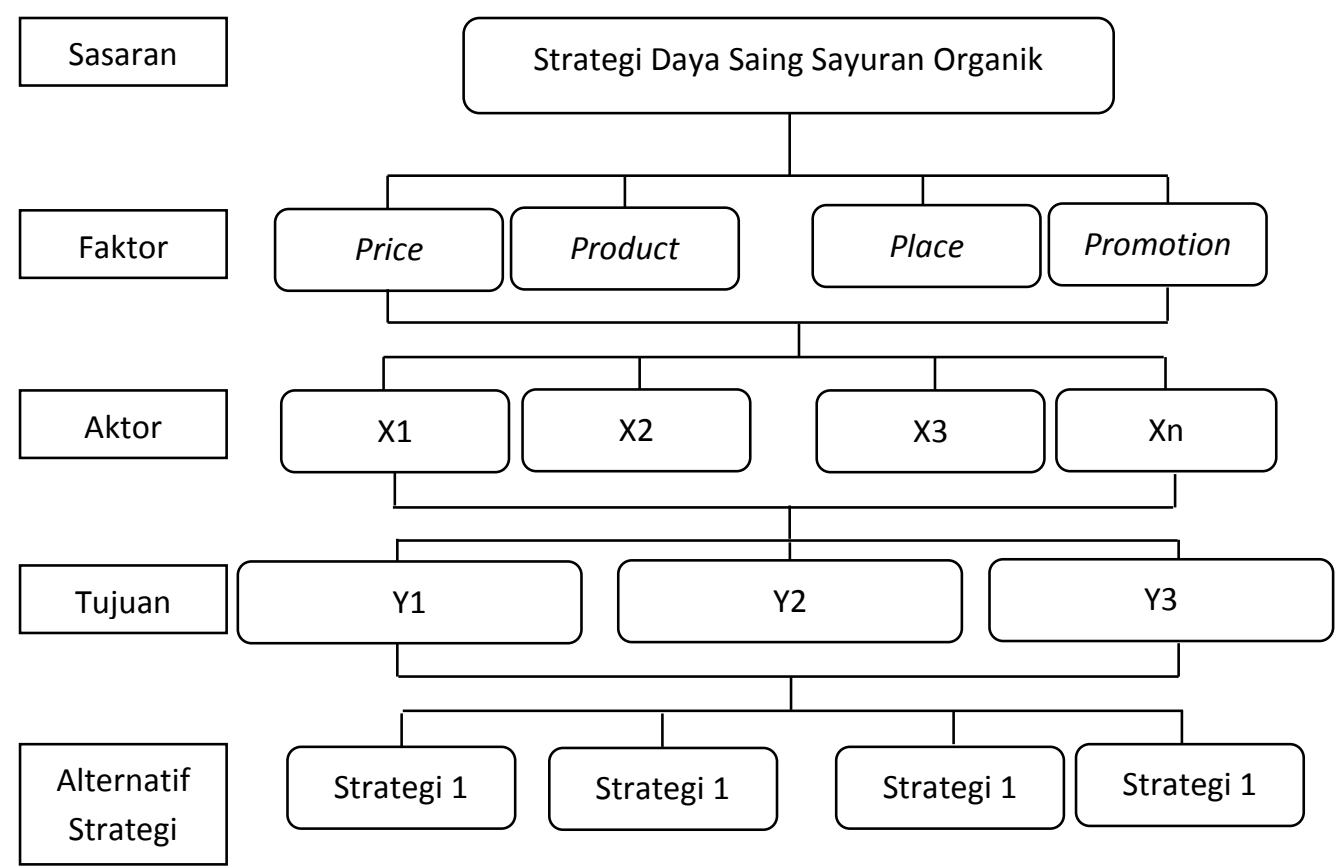

Gambar 4. Kerangka AHP

\section{Hasil dan Pembahasan}

\section{III.1. Gambaran Umum Sayuran Organik}

Sayuran organik didefinisikan menurut (Afifi 2007) sebagai suatu sistem produksi pertanian yang menghindarkan atau mengesampingkan penggunaan senyawa sintetik baik pupuk, zat tumbuh, maupun pestisida. Pertanian organik berbeda dengan penanaman secara konvensional yang memberikan unsur hara secara cepat dan langsung dalam membentuk larutan sehingga segera diserap dengan takaran dan waktu pemberian yang disesuaikan dengan kebutuhan tanaman. Penanaman sayuran organik diharapkan dapat mencegah kemungkinan dampak negatif yang muncul akibat penggunaan bahan-bahan kimia pada penanaman sayuran konvensional. Sistem dari pertanian organik sendiri diharapkan dapat meminimalisasi pencemaran berbahaya untuk lingkungan maupun bagi tubuh

III.2. Faktor-Faktor Kondisi yang Mempengaruhi Daya Saing Sayuran Organik dengan Menggunakan Porter's Diamond Model

Analisis ini mengidentifikasi faktor-faktor yang memengaruhi daya saing pada sayuran organik. Untuk menganalisis faktor-faktor tersebut digunakan alat analisis berdasarkan Porter's Diamond Model yang meliputi faktor kondisi, faktor kondisi permintaan, faktor industri terkait dan industri pendukung, faktor persaingan industri, faktor peran pemerintah, serta faktor peran kesempatan. Alat analisis yang kedua 
menggunakan Porter's Five Forces Model yang meliputi faktor persaingan antarperusahaan saingan, faktor potensi masuknya pesaing baru, faktor daya tawar pemasok, faktor yang dilihat dari daya tawar konsumen, serta faktor potensi pengembangan produk-produk pengganti. Dalam menentukan faktor yang memiliki pengaruh paling besar yang menggunakan lima responden pakar, digunakan skala 1-4 berdasarkan tingkat yang berpengaruh terhadap daya saing sayuran organik. Nilai 4 (sangat menentukan), nilai 3 (menentukan), nilai 2 (sedikit menentukan), nilai 1 (tidak menentukan).

Tabel 2. Faktor yang berpengaruh terhadap daya saing sayuran organik berdasarkan Porter's Diamond Model

\begin{tabular}{|c|c|c|c|c|c|c|c|}
\hline \multirow[t]{2}{*}{ NO } & \multirow[t]{2}{*}{ Atribut } & \multicolumn{4}{|c|}{ Nilai } & \multirow[t]{2}{*}{ Responden } & \multirow[t]{2}{*}{ Rataan Nilai } \\
\hline & & 1 & 2 & 3 & 4 & & \\
\hline & Faktor Kondisi & & & & & & \\
\hline 1 & Sumber daya Manusia (SDM) & - & - & 3 & 2 & 5 & 3.4 \\
\hline 2 & Sumberdaya Modal & - & - & 2 & 3 & 5 & 3.6 \\
\hline 3 & $\begin{array}{l}\text { Sumberdaya alam (SDA) dan } \\
\text { lingkungan }\end{array}$ & - & - & 2 & 3 & 5 & 3.6 \\
\hline 4 & Teknologi & - & - & 4 & 1 & 5 & 3.2 \\
\hline \multirow[t]{2}{*}{5} & Infrastruktur & - & - & 2 & 3 & 5 & 3.6 \\
\hline & Kondisi Permintaan & & & & & & \\
\hline 6 & $\begin{array}{l}\text { Jumlah pembeli dan tingkat } \\
\text { pertumbuhan }\end{array}$ & - & - & 3 & 2 & 5 & 3.4 \\
\hline \multirow[t]{2}{*}{7} & Preferensi konsumen & - & 2 & 3 & - & 5 & 2.6 \\
\hline & $\begin{array}{l}\text { Industri terkait dan industri } \\
\text { pendukung }\end{array}$ & & & & & & \\
\hline 8 & Pemasok & - & - & 4 & 1 & 5 & 3.2 \\
\hline 9 & Retail sayuran organik & - & - & 3 & 2 & 5 & 3.4 \\
\hline 10 & $\begin{array}{l}\text { Persaingan Industri } \\
\text { Tingkat persaingan retail sayuran } \\
\text { organik }\end{array}$ & - & 2 & 3 & - & 5 & 2.6 \\
\hline 11 & Strategi pesaing & - & 2 & 3 & - & 5 & 2.6 \\
\hline 12 & $\begin{array}{l}\text { Peran pemerintah } \\
\text { Regulasi }\end{array}$ & 1 & - & 1 & 3 & 5 & 3.2 \\
\hline 13 & $\begin{array}{l}\text { Peran kesempatan } \\
\text { Iklim Bisnis }\end{array}$ & - & 1 & 4 & - & 5 & 2.8 \\
\hline
\end{tabular}

Hasil analisis dengan Porter's Diamond Model menunjukkan bahwa atribut sumber daya modal, SDA dan lingkungan serta infrastruktur memiliki nilai rata-rata tertinggi, artinya bahwa atribut tersebut memilki pengaruh paling besar diantara atribut lainnya. Sedangkan atribut yang dianggap kurang berpengaruh dalam peningkatan daya saing sayuran organik adalah preferensi konsumen, tingkat persaingan retail sayuran. Pada Gambar 5 dapat dilihat Analisis peningkatan daya saing sayuran organik dengan menggunakan Porter's Diamond Model. 


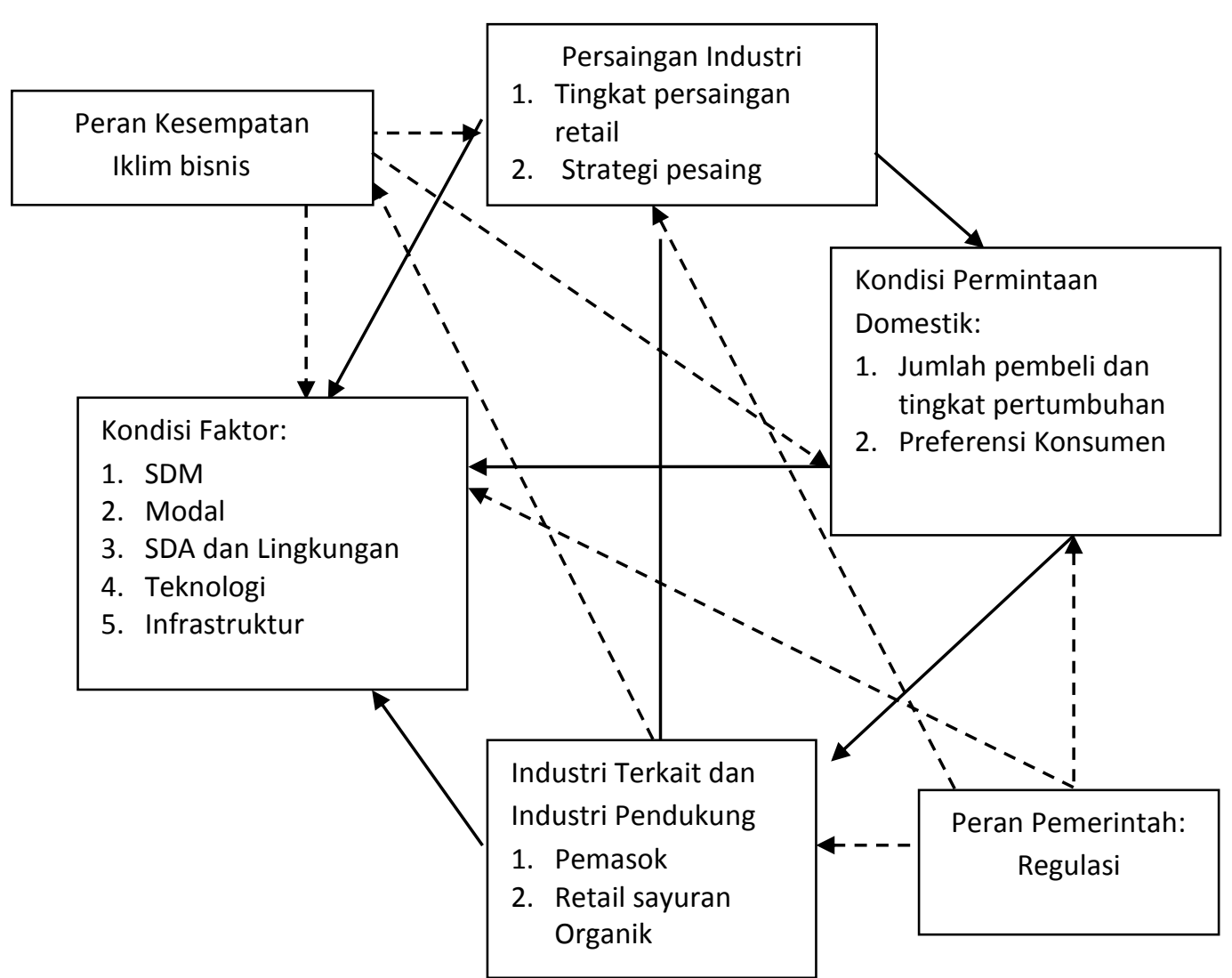

Gambar 5. Analisis peningkatan daya saing sayuran organik dengan menggunakan Porter's Diamond Model (Adaptasi Model)

Keterangan:

Garis ( ) menunjukan keterkaitan antara komponen utama yang saling mendukung

Garis (- - ) menunjukan keterkaitan antara komponen penunjang yang mendukung komponen utama

Dari Gambar 5 dapat dijelaskan bahwa pada usaha sayuran organik, terdapat empat faktor utama yang memengaruhi jalannya usaha ini yakni persaingan industri yang meliputi tingkat persaingan antar retail dan strategi yang digunakan, kondisi permintaan domestik seperti jumlah pembeli dengan preferensi konsumen akan produk sayuran organik yang dihasilkan, kondisi faktor diantaranya SDM, SDA, modal, teknologi, dan infrastruktur. Faktor utama yang terakhir adalah industri terkait dan industri pendukung yang meliputi retail dan pemasok. Selain itu terdapat dua faktor pendukung diluar dari empat faktor utama yang mempengaruhi daya saing sayuran organik, dimana kedua faktor tersebut berada diluar kendali pemilik usaha sayuran organik. Faktor tersebut adalah faktor kesempatan dan peran pemerintah berupa regulasi yang dikeluarkan untuk mengatur jalannya usaha ini.

\section{III.3.Faktor-Faktor Kondisi yang Mempengaruhi Daya Saing Sayuran Organik dengan Menggunakan Porter's Five Forces Model}

Hasil analisis dengan menggunakan Porter's Five Forces Model untuk mengetahui faktor-faktor kondisi yang memengaruhi peningkatan daya saing sayuran organik dapat dilihat pada Tabel 3. 
265|Priastuti, Suroso, Najib - Analisis Strategi Peningkatan Daya Saing Sayuran Organik

Tabel 3. Faktor-Faktor yang berpengaruh terhadap daya saing sayuran organik berdasarkan Porter's Five Forces Model

\begin{tabular}{|c|c|c|c|c|c|c|c|}
\hline \multirow[t]{2}{*}{ NO } & \multirow[t]{2}{*}{ Atribut } & \multicolumn{4}{|c|}{ Nilai } & \multirow[t]{2}{*}{ Responden } & \multirow{2}{*}{$\begin{array}{c}\text { Rataan } \\
\text { Nilai }\end{array}$} \\
\hline & & 1 & 2 & 3 & 4 & & \\
\hline & $\begin{array}{l}\text { Persaingan antar perusahaan saingan } \\
\text { (New Entrants) }\end{array}$ & & & & & & \\
\hline 1 & Pesaing Lama & - & 2 & 3 & - & 5 & 2.6 \\
\hline \multirow[t]{2}{*}{2} & Keunggulan Pesaing & - & - & 3 & 2 & 5 & 3.4 \\
\hline & $\begin{array}{l}\text { Potensi masuknya pesaing baru } \\
\text { (Competitor) }\end{array}$ & & & & & & \\
\hline 3 & Munculnya Pesaing baru & 1 & 2 & 2 & - & 5 & 2.2 \\
\hline \multirow[t]{3}{*}{4} & $\begin{array}{l}\text { Dampak yang diberikan oleh pesaing } \\
\text { baru }\end{array}$ & - & 3 & 2 & - & 5 & 2.4 \\
\hline & Daya tawar pemasok (Bargaining & & & & & & \\
\hline & Power of suppliers) & & & & & & \\
\hline 5 & Kekuatan Pemasok & - & - & 2 & 3 & 5 & 3.6 \\
\hline 6 & $\begin{array}{l}\text { Pengaruh pemasok terhadap usaha } \\
\text { sayuran organik }\end{array}$ & - & 1 & 4 & - & 5 & 2.8 \\
\hline \multirow[t]{2}{*}{7} & Pemilihan Pemasok Sayuran organik & - & 1 & 3 & 1 & 5 & 3 \\
\hline & $\begin{array}{l}\text { Dilihat dari Daya tawar konsumen } \\
\text { (Bargaining power of buyer) }\end{array}$ & & & & & & \\
\hline \multirow[t]{2}{*}{8} & Pengaruh Konsumen/Pembeli & - & 2 & 2 & 1 & 5 & 2.8 \\
\hline & $\begin{array}{l}\text { Potensi pengembangan produk-produk } \\
\text { pengganti (Subtitute product) }\end{array}$ & & & & & & \\
\hline 9 & Munculnya Produk subtitusi & 1 & 2 & 2 & - & 5 & 2.2 \\
\hline 10 & Pengaruh produk subtitusi & 1 & 3 & 1 & - & 5 & 2 \\
\hline
\end{tabular}

Dari hasil analisis tersebut dapat diketahui bahwa atribut yang memiliki nilai tertinggi adalah kekuatan pemasok dengan nilai rataan 3.60. Sementara atribut yang memiliki nilai paling rendah adalah pengaruh produk substitusi dengan nilai 2.00 . Kerangka model analisis peningkatan daya saing sayuran organik dengan menggunakan Porter's Five Forces Modeldapat dilihat pada Gambar 6.

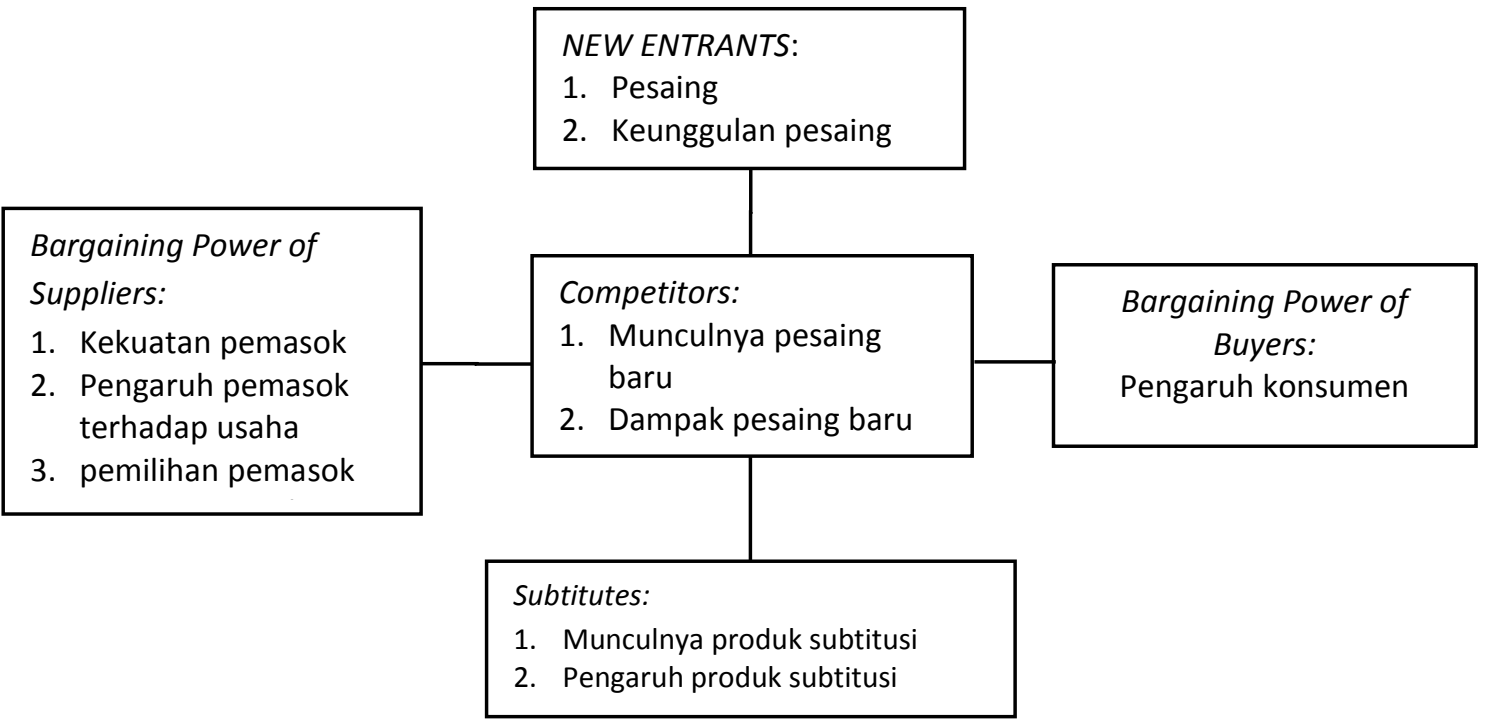

Gambar 6. Analisis peningkatan daya saing sayuran organik dengan menggunakan Porter's Five Forces Model 
Dari Gambar 6 dapat dijelaskan bahwa competitor yang masuk akibat adanya pesaing dan dampak yang diberikan berada pada tingkat retail. Retail sayuran organik harus waspada akan munculnya pesaing-pesaing baru yang akan mempengaruhi usahanya. Oleh karena itu, untuk mendukung kekuatan suatu retail untuk bertahan dalam persaingan, dibutuhkan suatu kekuatan yang akan membantu retail dalam menghadapi persaingan pasar sayuran organik. Kekuatan tersebut diantaranya dengan pemilihan pemasok sayuran organik bermutu baik dan melihat pengaruh dari pemilihan pemasok tersebut terhadap usaha yang dijalankan. Pemilihan pemasok ini memiliki pertimbangan seperti adanya pengaruh yang yang diberikan oleh konsumen. Konsumen dapat memengaruhi retail dalam pemilihan pemasok seperti permintaan khusus konsumen mengenai mutu, harga , dan sayuran-sayuran organik jenis tertentu. Ancaman akan selalu ada dalam setiap usaha. Pada usaha ini, ancaman yang muncul berasal dari pesaing dan produk subtitusi sayuran organik. Pesaing pasti memiliki keunggulan-keunggulan yang dapat merebut pasar, oleh karena itu dibutuhkan suatu studi pasar untuk melihat keunggulan yang dimiliki pesaing yang nantinya akan digunakan dalam penentuan strategi apa yang seharusnya digunakan untuk meningkatkan daya saing sayuran organik. Munculnya produk subtitusi dari sayuran organik perlu di waspadai agar sayuran organik tidak kalah bersaing dipasaran.

\section{III.4. Alternatif Strategi Untuk Meningkatkan Daya Saing Sayuran Organik}

Setelah mengetahui faktor-faktor kondisi yang mempengaruhi daya saing sayuran organik, selanjutnya dilakukan analisis untuk menetukan alternatif strategi Porter's Generic Strategies. Strategi generik menurut Porter dibagi menjadi 3, yaitu strategi keunggulan biaya menyeluruh, strategi diferensiasi dan strategi fokus. Setiap tujuan dibuat alternatif strateginya dan selanjutnya dilakukan analisis hirarki proses untuk menentukan prioritas strategi untuk diterapkan dalam menjalankan usaha sayuran organik.

Terdapat 3 hal yang menjadi tujuan untuk meningkatkan daya saing, yaitu meningkatkan mutu hasil produksi, meningkatkan penjualan, dan memperluas pangsa pasar, yaitu:

1. Untuk meningkatkan mutu hasil produksi, digunakan strategi generik porter diferensiasi. Strategi yang dipilih adalah mengontrol mutu produk dan strategi fokus dengan melakukan pelatihan intensif bagi petani produksi.

2. Untuk meningkatkan penjualan, digunakan strategi fokus dengan alternatif strategi menghasilkan produk mutu tinggi dan membangun citra positif dalam industri.

3. Untuk memperluas pangsa, digunakan strategi fokus dengan alternatif strategi bermitra dengan pemasok sayuran organik.

\section{III.5. Alternatif Strategi yang Menjadi Prioritas dalam Meningkatkan Daya Saing}

Analisis selanjutnya meyusun hirarki dengan melihat sasaran, faktor-faktor, aktor, tujuan, dan strategi yang telah di analisis pada tahapan sebelumnya dengan menggunakan alat analisis berupa Porter's Diamond Model dan Porter's Five Forces Model untuk menganalisis faktor-faktor kondisi yang memengaruhi peningkatan daya saing sayuran organik dan Porter's Generic Strategic yang digunakan untuk 
menentukan alternatif-alternatif strategi yang dapat digunakan untuk meningkatkan daya saing. AHP merupakan salah satu metode untuk membantu menyusun suatu prioritas dari berbagai pilihan dengan menggunakan beberapa kriteria (multi criteria). Di samping bersifat multi kriteria, AHP juga didasarkan pada suatu proses yang terstruktur dan logis. Pemilihan atau penyusunan prioritas dilakukan dengan suatu prosedur yang logis dan terstruktur. Pengolahan data menggunakan AHP memiliki dua sudut pandang, yaitu pengolahan secara horizontal dan pengolahan secara vertikal. Pengolahan horizontal menunjukan besarnya tingkat pengaruh suatu unsur dengan unsur lainnya terhadap hirarki yang berada tepat diatasnya. Sedangkan pengolahan vertikal menunjukan pengaruh masing-masing unsur dalam suatu hirarki terhadap fokus utama. AHP dari meningkatkan daya saing sayuran organik dapat dilihat pada Gambar 7.

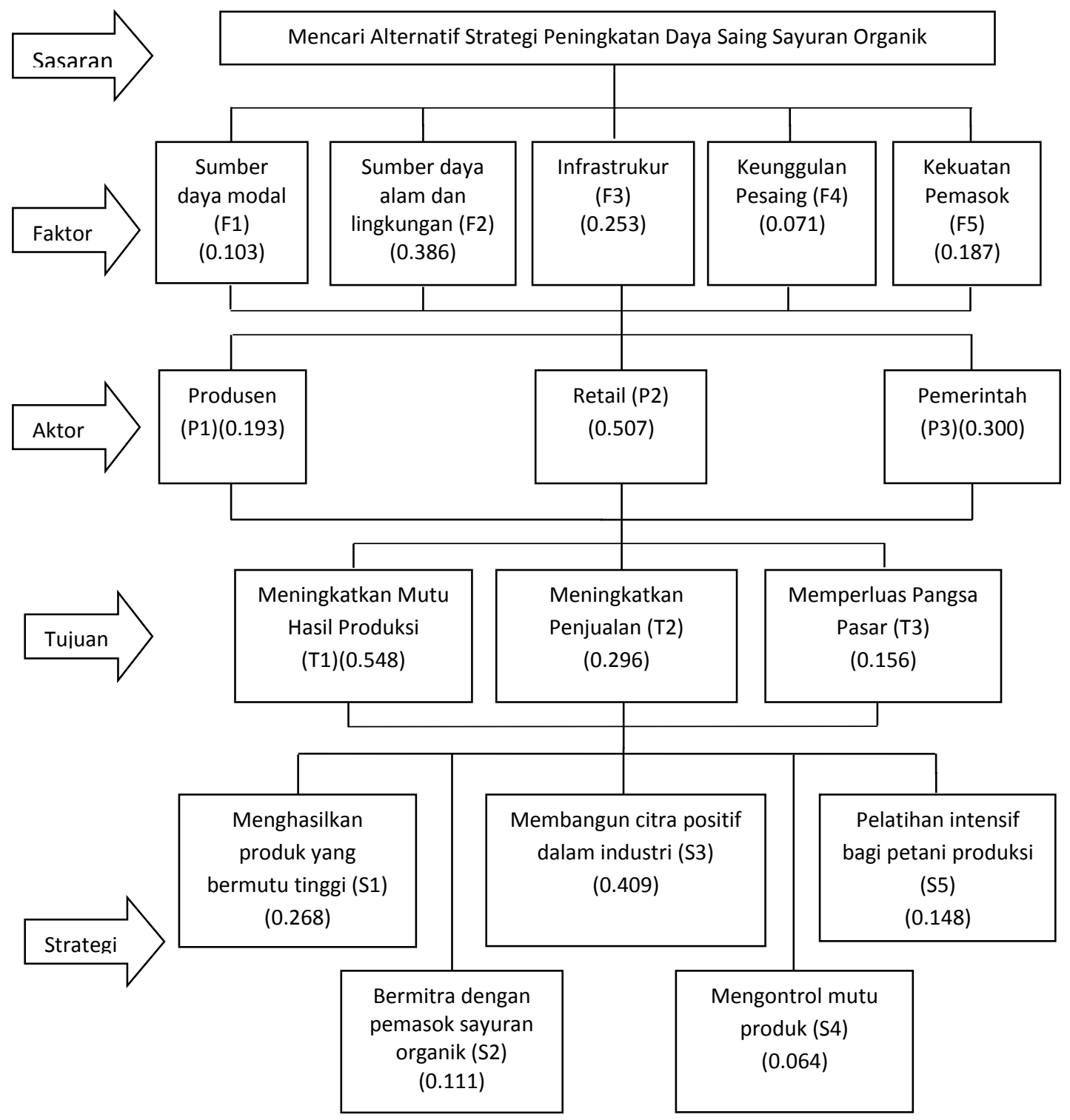

Gambar 7. Struktur AHP pada daya saing sayuran organik 
Sasaran dari penyusunan AHP pada penelitian ini adalah mencari alternatif strategi peningkatan daya saing sayuran organik dengan faktor-faktor yang dianggap paling berpengaruh oleh pakar yaitu Sumber daya Modal (F1), SDA dan lingkungan (F2), Infrastruktur (F3), Keunggulan Pesaing (F4) dan Kekuatan Pemasok (F5). Selanjutnya ditetapkan aktor yang memegang peranan dalam meningkatkan daya saing diantaranya Produsen (P1), Retail (P2), dan Pemerintah (P3). Hasil diskusi dengan para pakar didapatkan bahwa aktor yang paling berperan dalam meningkatkan daya saing sayuran organik adalah Retail (P2). Tujuan yang hendak dicapai dalam meningkatkan daya saing sayuran organik adalah Meningkatkan kualitas hasil produksi (T1), Meningkatkan penjualan (T2) dan Memperluas pangsa pasar (T3). Setelah dilakukan perhitungan, didapatkan hasil meningkatkan hasil produksi (T1) sebagai tujuan utama yang dilakukan oleh Retail untuik meningkatkan mutu hasil produksi. Jika dilihat dari perannya, meningkatkan mutu bukan peran dari retail. Retail sendiri berperan secara tidak langsung dalam meningkatkan mutu hasil produksi sayuran organik. Dalam kasus ini, retail hanya mengontrol petani produksi untuk tetep mempertahankan mutu sayuran yang baik atau meningkatkan mutu hasil produksinya. Jika sayuran yang dihasilkan petani bermutu rendah atau kurang baik, retail dapat memutuskan kontrak atau memilih pemasok lain yang dapat memenuhi standar produk yang dijual pada retail tersebut. Oleh karena itu, retail memegang peranan paling besar dalam meningkatkan mutu sayuran organik dalam meingkatkan daya saing, walaupun retail sendiri tidak memproduksi langsung sayuran tersebut.

Tahap terakhir dalam penyusunan hirarki adalah menetapkan alternatif-alternatif strategi yang dapat diambil berkaitan dengan strategi peningkatan daya saing sayuran organik, yaitu: Menghasilkan produk bermutu tinggi (S1), Bermitra dengan pemasok sayuran organik (S2), Membangun citra positif dalam industri (S3), Mengontrol mutu produk (S4) dan Pelatihan intensif bagi petani produksi (S5). Adapun strategi yang digunakan merupakan hasil pemikiran para pakar yang menjadi sumber dalam penelitian. Strategi yang memiliki nilai tertinggi adalah membangun citra positif dalam industri. Strategi ini diterapkan oleh retail guna menciptakan kepercayaan dan loyalitas konsumen sayuran organik. Citra posisitf dari suatu usaha berbanding lurus dengan kepercayaan yang didapatkan. Seiring dengan citra positif yang diperoleh maka akan didapatkan kepercayaan dan loyalitas konsumen untuk membeli produk sayuran organik di retail tersebut.

\section{III.6. Implikasi Manajerial}

Implikasi manajerial yang dilakukan para pelaku usaha sayuran organik adalah: dalam bidang produksi, diperlukan penerapan teknologi yang modern pada produksi sayuran organik untuk meningkatkan mutu produk yang dihasilkan. Teknologi dapat digunakan adalah mesin untuk pembasmian hama, penyiraman tanaman, penyebaran pupuk dan pengepakan. Penerapan teknologi ini sebelumnya memerlukan sosialisasi mengenai pengenalan, cara guna dan manfaat yang didapatkan, misalnya mempermudah dalam pekerjaan, sehingga memungkinkan terjadinya produksi massal dan selain itu efisiensi waktu dan tenaga kerja untuk menekan biaya produksi.

Dalam bidang produksi melakukan pengawasan pada proses produksi untuk meningkatkan mutu dan daya tahan produk. Apabila produk yang dihasilkan baik, 
maka citra positif akan didapatkan oleh pelaku usaha sayuran organik. Dalam bidang manajemen motivasi dan semangat kerja bagi para petani maupun pegawai di bidang produksi harus ditingkatkan untuk mengurangi stres dan kejenuhan bekerja. Kegiatan untuk mengurangi hal negatif adalah dengan kegiatan membangun hubungan kekeluargaan, baik secara vertikal maupun secara horizontal. Dengan adanya motivasi yang tinggi pada pegawai, maka akan menghasilkan produktivitas tinggi. Dampak positifnya adalah terjadinya peningkapan kapasitas produksi, skala usaha dan kesejahteraan.

Hal lain dalam bidang manajemen: mengetahui kemampuan pesaing dalam menerapkan strategi usaha, diperlukan perbandingan kinerja dengan pelaku usaha sayuran organik lain. Setelah mengamati bagaimana pesaing bekerja, dapat dilakukan proses evaluasi memperbaiki diri untuk meningkatkan produktivitas dan mutu pada sayuran organik yang dihasilkan. Dalam bidang pemasaran: kerjasama dengan beberapa pelaku bisnis lain seperti pemasok, retail, dan supermarket sangat dianjurkan dengan tujuan meningkatkan pangsa pasar dengan menjual produk lebih banyak yang lebih merata. Promosi atau beriklan juga penting untuk dilakukan dengan harapan konsumen lebih mengetahui tentang usaha sayuran organik dan menumbuhkan kepercayaan konsumen terhadap sayuran organik yang dijual, sehingga permintaan akan sayuran organik meningkat.

\section{Kesimpulan}

Berdasarkan hasil penelitian yang telah dilakukan, maka dapat disimpulkan bahwa faktor-faktor kondisi yang paling berpengaruh terhadap peningkatan daya saing sayuran organik adalah sumberdaya modal, SDA dan lingkungan, infrastruktur, kekuatan pemasok. Sedangkan faktor yang memiliki pengaruh paling rendah adalah pengaruh produk subtitusi.

Terdapat lima prioritas strategi yang disusun dengan menggunakan Porter's generic strategic untuk meningkatkan daya saing sayuran organik adalah menghasilkan produk bermutu tinggi, bermitra dengan pemasok sayuran organik, membangun citra yang positif dalam industri, mengontrol kualitas produk dan pelatihan yang intensif bagi petani produksi.

Alternatif strategi yang prioritasnya paling tinggi untuk dipilih adalah strategi membangun citra yang positif dalam industri, sebagai upaya meningkatkan daya saing dari kalangan pelaku usaha sayuran organik dengan cara meningkatkan kepercayaan dan loyalitas konsumen untuk tetap membeli produk sayuran organik.

\section{Daftar Pustaka}

Afifi MF. 2007. Analisis Kepuasan Konsumen terhadap Atribut Sayuran Organik dan Penerapan Personal SellingBenny's Organic Garden. [Skripsi]. Bogor (ID) : Institut Pertanian Bogor

[AOI] Aliansi Organik Indonesia. 2011. Statistik Pertanian Organik Indonesia 2011. Bogor (ID): AOI. 
Priastuti, Suroso, Najib - Analisis Strategi Peningkatan Daya Saing Sayuran Organik|270

[BPS] Badan Pusat Statistik. 2013. Produksi Sayuran di Indonesia Tahun 2008-2012. [Internet]. [diunduh pada 2013 Mei 14]. Tersedia pada: www.bps.go.id.

David FR. 2006. Manajemen Strategis: Konsep. Edisi 10. (Terjemahan). Jakarta (ID): Penerbit Salemba Empat.

Direktorat Jenderal Hortikultura. 2010. Statistik Produksi Hortikultura. Jakarta (ID): Direktorat Jenderal Bina Produksi Hortikultura.

Porter ME. 1994. Keunggulan Bersaing: Menciptakan dan Mempertahankan Kinerja Unggul. Jakarta (ID): Binarupa Aksara.

Saaty TL. 1991. Pengambilan Keputusan Bagi Para Pemimpin: Proses Hirarki Analitik Untuk Pengambilan Keputusan Dalam Situasi Yang Komplek. (Terjemahan). Jakarta (ID): PT Pustaka Binaman Pressindo.

Tambunan HTT. 2013. Kebijakan Industri dalam menyongsong ME-ASEAN 2015. Policy Paper,16. Jakarta (ID): Kadin Indonesia. 